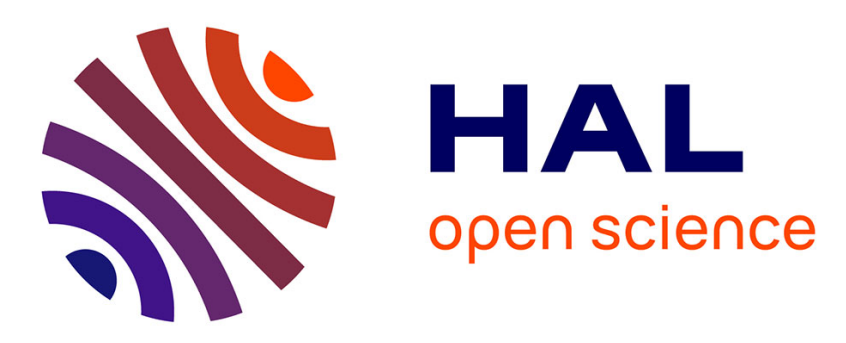

\title{
Magnetoresistance Effect in the La1-xSrxMnO3 Ceramics
}

\author{
N. Ichinose, A. Nakamura
}

\section{To cite this version:}

N. Ichinose, A. Nakamura. Magnetoresistance Effect in the La1-xSrxMnO3 Ceramics. Journal de Physique IV Proceedings, 1997, 07 (C1), pp.C1-631-C1-632. 10.1051/jp4:19971260 . jpa-00254969

\section{HAL Id: jpa-00254969 https://hal.science/jpa-00254969}

Submitted on 1 Jan 1997

HAL is a multi-disciplinary open access archive for the deposit and dissemination of scientific research documents, whether they are published or not. The documents may come from teaching and research institutions in France or abroad, or from public or private research centers.
L'archive ouverte pluridisciplinaire HAL, est destinée au dépôt et à la diffusion de documents scientifiques de niveau recherche, publiés ou non, émanant des établissements d'enseignement et de recherche français ou étrangers, des laboratoires publics ou privés. 


\title{
Magnetoresistance Effect in the $\mathrm{La}_{1-x} \mathrm{Sr}_{x} \mathrm{MnO}_{3}$ Ceramics
}

\author{
N. Ichinose and A. Nakamura \\ Waseda University, School of Science and Engineering, 3-4-1 Ohkubo, Shinjuku-ku, Tokyo, 169, Japan
}

\begin{abstract}
In this paper, we present the experimental investigation on the MR effect with particular emphasis on the ceramic processing of the $\mathrm{La}_{1-\mathrm{x}} \mathrm{Sr}_{\mathrm{x}} \mathrm{MnO}_{3}$ system. The MR ratio is defined here as $\Delta \rho / \rho(\mathrm{H})=$ $(\rho(\mathrm{H})-\rho(0) / \rho(\mathrm{H})$ where $\rho(0)$ is the zero field resisitance and $\rho(\mathrm{H})$ the resisitivity in the applied magnetic field, e.g., $\mathrm{H}=1000 \mathrm{kA} / \mathrm{m}$. The $\mathrm{MR}$ ratio is dependent on the chemical composition and firing conditions. At room temperature, the higher $\Delta \rho / \rho(\mathrm{H})$ value of $\sim 12 \%$ has been obtained for the $\mathrm{La}_{0.8} \mathrm{Sr}_{0.2} \mathrm{MnO}_{3}$ ceramics fired at 1673K. This value is comparable to higher values for the so-called "giantmagnetoresistance(GMR)" -type materials of metallic multilayer. The order of magnitude change in electrical resistivity could be useful for various magnetic and electric device applications.
\end{abstract}

\section{INTRODUCTION}

The ferromagnetic state in the $\mathrm{La}_{1-x} \mathrm{Sr}_{x} \mathrm{MnO}_{3}$ system has been known as a prototypical example for the double-exchange interaction. ${ }^{1)}$ The $\mathrm{Mn}^{3+}$ ion in normally hole-undoped $\mathrm{LaMnO}_{3}$ has the electrons on the $\mathrm{Mn}$ site, $\mathrm{t}_{2 \mathrm{~g}}{ }^{3} \mathrm{e}_{\mathrm{g}}{ }^{1}$. Among the four $3 d$ electrons on the $\mathrm{Mn}$ site, $\mathrm{t}_{2 \mathrm{~g}}{ }^{3}$ electrons may be viewed as a local spin $(\mathrm{S}=3 / 2)$ because of the relatively poor hybridzation with $\mathrm{O} 2 \mathrm{p}$ states, while the strongly hybridzed $\mathrm{e}_{\mathrm{g}}{ }^{1}$ state is either itinerant or localized. Therefore deviation of $\mathrm{e}_{\mathrm{g}}$ electron, or the so-called hole doping governs the electronic properties including temperature and field-dependent metal-nonmetal phenomena. In 1969 the first magnetoresistance(MR) measurements were reported on a flux-grown single crystal of $\mathrm{La}_{1-x} \mathrm{Sr}_{\mathbf{x}} \mathrm{MnO}_{3}(\mathrm{x}=0.31)$.2) Recently, La-manganite thin films have been prepared and MR behavior has been reported for $\left.\mathrm{La}-\mathrm{Ba}-\mathrm{Mn}-\mathrm{O}^{3}\right)$ and $\mathrm{La}-\mathrm{Ca}-\mathrm{Mn}-\mathrm{O}^{4}$ ).

In this article, we report the electrical, magnetic, and magnetoresistance behaviour in $\mathrm{La}-\mathrm{Sr}-\mathrm{Mn}-\mathrm{O}$ ceramics forcused for the ceramic processing.

\section{Experimental}

Ceramic samples were prepared by the conventional method. Raw materials $\mathrm{La}_{2} \mathrm{O}_{3}, \mathrm{SrCO}_{3}$ and $\mathrm{MnO}_{2}$ were mixed and calcined at $1273 \mathrm{~K}$ for $24 \mathrm{~h}$ in air. After pulverization, the calcined powder was supplemented with polyvinyl alcohol binder. The powder was granulated and cold pressed into disks under a pressure of $1 \mathrm{Ton} / \mathrm{cm}^{2}$. These disks were sintered 
at $1473 \sim 1773 \mathrm{~K}$ for $3 \mathrm{~h}$ in air. Some samples were quenched from $1573 \mathrm{~K}$ and annealed at $1273 \mathrm{~K}$ for $40 \mathrm{~h}$ in air.

Densities were measured by Archimedes method. The final products were examined by X-ray diffraction using CuK $\alpha$ radiation.The magnetic field dependence of the resistivity of samples was measured for the determination of MR ratio.

\section{Results and discussion}

The densities of samples were increasing withthe increase of sintering temperature and over $95 \%$ of relative density at 1673K. X-ray diffraction patterns show that only single perovskite phase exists for the range of $0.4 \geqq x \geqq 0$ in the $\left(\mathrm{La}_{1 . x} \mathrm{Sr}_{\mathrm{z}}\right) \mathrm{MnO}_{3}$ system. As the ionic radius of $\mathrm{Sr}^{2+}$ is smaller than that of $\mathrm{La}^{3+}$, the resultant lattice parameter of the essentially cubic La-Sr-Mn-O perovskite material decreases monotonically with the amount of Sr substitution reaching 3.877A for $\mathrm{Sr}_{0.2}$ smaller than $\mathrm{a} \sim 3.895 \AA$ for the $\mathrm{LaMnO}_{3}$ material. Figures 1 and 2 show the MR ratio vs magnetic field for furnace cooled and quenched samples, respectively. It is found from these figures that the higher MR ratio is obtained at around $x_{2} 0.2$. The reason for the improvement of $\mathrm{MR}$ ratio in the $\mathrm{La}_{1-\mathrm{xSr}} \mathrm{MnO}_{3}$ system is not clearly understood but one of the possible explanations is that the modification of MR behavior is due to a lattice parameter decrease which is induced by the partial substitution of $\mathrm{La}^{3+}$ (ionic radius $\sim 1.15 \AA$ ) with smaller $\mathrm{Sr}^{2+}$ ( ionic radius $\sim 1.13 \AA$, ${ }^{5}$ ?

In conclusion, the highest $\Delta \rho / \rho(\mathrm{H})$ value of $\sim 12 \%$ has been obtained for the $\left(\mathrm{La}_{0.8} \mathrm{Sr}_{0.2)}\right) \mathrm{MnO}_{3}$ ceramics at room temperature. The order of magnitude of change in electrical resistivity could be useful for various magnetic device applications.

\section{References}

1) C. Zener ; Phys.Rev. 82 (1951) 403

2) C. W. Searle et. al. ; Can.J.Phys. 47 (1969) 2023

3) R. von. HemloIt et. al. ; Phys.Rev.Lett. 71 (1993) 2331

4) K. Chahara et. al. ; Appl.Phys.Lett. 63 (1993) 1990

5) S. Jin H.M. O'Bryan, T.H. Tiefel, M. McCormack and W.W. Rhodes. ; Appl.Phys.Lett. 66 (1995) 382

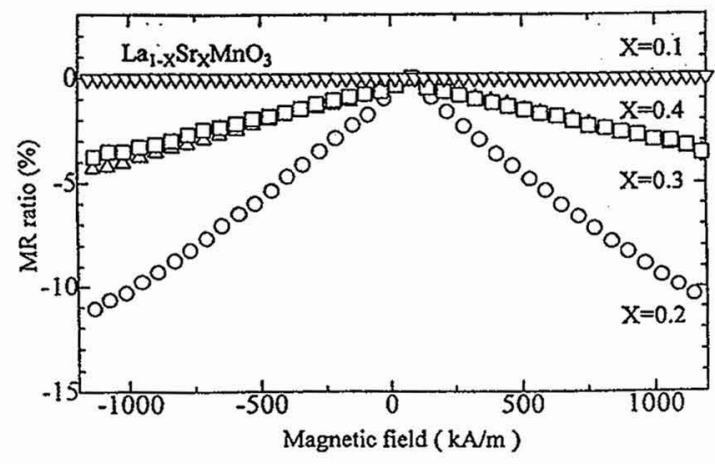

Fig. 1 MR curves for furnace-cooled samples.

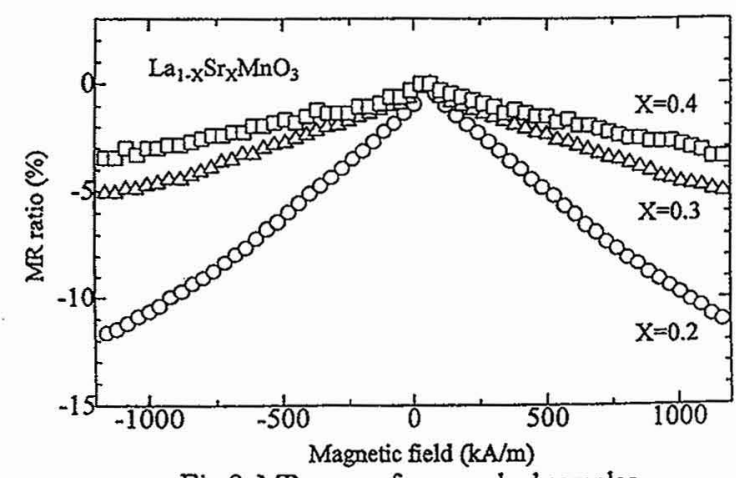

Fig.2 MR curves for quenched samples. 